\title{
Hubungan Waktu Intubasi terhadap Tingkat Mortalitas Pasien dengan COVID-19 Berat: Sebuah Tinjauan Sistematis
}

\author{
Riyadh Firdaus ${ }^{1 *}$, Sandy Theresia ${ }^{2}$, Ryan Austin ${ }^{2}$, Rani Tiara ${ }^{3}$ \\ 1. Departemen Anestesiologi dan Terapi Intensif, Fakultas Kedokteran Universitas Indonesia, \\ RSUPN Dr. Cipto Mangunkusumo, Jakarta, Indonesia \\ 2. Fakultas Kedokteran dan IImu Kesehatan, Universitas Katolik Indonesia Atma Jaya, Jakarta \\ 3. Fakultas Kedokteran Universitas Lampung, Lampung
}

\begin{abstract}
ABSTRAK
Pendahuluan: Severe acute respiratory syndrome coronaviruses 2 (SARS-CoV-2) yang dikenal dengan coronavirus disease 2019 (COVID-19) mulai menginfeksi manusia pada akhir tahun 2019. Orang yang terinfeksi dapat menunjukkan keadaan asimtomatik hingga keadaan mengancam nyawa. Keadaan acute respiratory distress syndrome (ARDS) merupakan kondisi berat pada infeksi COVID-19 yang membutuhkan penanganan lebih lanjut, di antaranya adalah pertimbangan untuk dilakukan intubasi. Penelitian ini bertujuan membandingkan hubungan waktu dilakukannya intubasi terhadap tingkat mortalitas dari pasien COVID-19 yang terintubasi.

Metode: Penelitian tinjauan sistematik ini dibuat berdasarkan panduan PRISMA-P. Data dikumpulkan dari basis data Pubmed, Cochrane Library, dan ProQuest dengan kriteria inklusi berupa penelitian randomized control trial dan studi kohort yang meneliti tindakan intubasi pada pasien dengan COVID-19. Dari sebanyak sebanyak 8.297, didapatkan 3 artikel yang memenuhi kriteria inklusi dan eksklusi pada tinjauan literatur.

Hasil: Dari ketiga literatur yang kami lakukan analisis, didapatkan hasil bahwa tidak ada perbedaan yang signifikan mengenai kapan dilakukannya intubasi dengan angka kejadian mortalitas pasien COVID-19. Baik pada intubasi yang dilakukan lebih awal ataupun pada intubasi yang lebih lambat. Karakteristik pasien usia tua dan memiliki komorbiditas dapat memperburuk keadaan yang membuat angka mortalitas pada kelompok tersebut lebih tinggi.

Kesimpulan: Berdasarkan penelitian yang kami lakukan, intubasi lebih awal (<8 jam) tidak menurunkan angka mortalitas pada pasien COVID-19, sehingga masih diperlukan penelitian lebih lanjut terkait faktor prediktif lainnya.
\end{abstract}

Kata Kunci: COVID-19, intubasi, mortalitas, ventilasi mekanik, tinjauan sistematis 


\title{
Correlation of Timing of Intubation and Mortality Rates in Patients with Severe COVID-19: A Systematic Review
}

\author{
Riyadh Firdaus ${ }^{1 *}$, Sandy Theresia ${ }^{2}$, Ryan Austin ${ }^{2}$, Rani Tiara ${ }^{3}$ \\ 1. Department of Anesthesiology and Intensive Care, Faculty of Medicine, Universitas \\ Indonesia, Dr. Cipto Mangunkusumo National General Hospital, Jakarta, Indonesia \\ 2. Faculty of Medicine and Health Science, Atma Jaya Catholic University of Indonesia, Jakarta \\ 3. Faculty of Medicine, Universitas Lampung, Lampung \\ *corresponding author
}

\begin{abstract}
Introduction: Severe acute respiratory syndrome coronaviruses 2 (SARS-CoV-2), known as coronavirus disease 2019 (COVID-19), started infecting humans in late 2019. An infected person can develop asymptomatic to life threatening conditions. The state of acute respiratory distress syndrome (ARDS) is a severe condition in COVID-19 infection that requires further treatment, including consideration for intubation. This study aims to compare the correlation between the timing of intubation and the mortality rate of intubated COVID-19 patients.

Method: This systematic review research is based on PRISMA-P guidelines. Data were collected from the Pubmed, Cochrane Library, and ProQuest databases with the inclusion criteria of a randomized control trial and a cohort study that examined intubation in patients with COVID-19. From a total of 8,297, there were 3 articles that met the inclusion and exclusion criteria in the literature review.

Results: From the three literatures that we analysed, it was found that there was no significant difference between when to intubate and the mortality incidence of COVID-19 patients. Either on an earlier intubation or a later one. The characteristics of patients who are old and with comorbidities can exacerbate the situation that makes the mortality rate in this group higher.

Conclusion: Based on our study, earlier intubation (<8 hours) did not reduce mortality in COVID-19 patients, however, further research is needed regarding other predictive factors.
\end{abstract}

Keywords: COVID-19, intubation, mortality, mechanical ventilation, systematic review 


\section{PENDAHULUAN}

Akhir tahun 2019 telah terjadi wabah pneumonia yang belum diketahui penyebabnya. Pertama kali diinformasikan terjadi di Wuhan, China dan menginfeksi sebagian masyarakat wilayah tersebut. ${ }^{1}$ Severe acute respiratory syndrome coronaviruses 2 (SARS-CoV-2) yang dikenal dengan coronavirus disease 2019 (COVID-19), merupakan virus baru yang berasal dari family Coronaviridae dengan single-strand RNA positif dan memiliki envelope, yang diketahui berasal dari kelelawar pembawa SARS-like coronavirus, kemudian menginfeksi manusia setelah beberapa mutasi dalam glikoprotein spike (protein S) dan protein nukleokapsid (protein N). ${ }^{2,3}$ Data epidemiologi menunjukkan angka positif COVID-19 seluruh dunia sejauh ini sudah mencapai 115 juta kasus dan angka mortalitas mencapai 2,5 juta kematian. ${ }^{4}$

Pasien yang terinfeksi COVID-19 memiliki gejala yang bervariasi, dari asimtomatik hingga mengancam nyawa. Gejala awal yang muncul pada infeksi COVID-19 biasanya berupa keluhan demam, batuk kering, dan kelelahan. ${ }^{5}$ Patofisiologi dasar pneumonia viral berat adalah gagal napas sekunder hingga acute respiratory distress syndrome (ARDS). Uniknya, tidak semua pasien COVID-19 dengan hipoksia yang signifikan menunjukkan gejala yang tampak seperti gagal napas. Meskipun pasien ini tampak cukup stabil pada awalnya, dekompensasi pernapasan sering terjadi. Jika dekompensasi tidak dapat mempertahankan kebutuhan oksigenasi tubuh maka perburukan akan cepat terjadi dan membuat proses intubasi menjadi berbahaya. ${ }^{6}$ Maka dari itu, beberapa ahli dari
Cina, Eropa, dan Amerika Serikat mendukung strategi untuk dilakukan intubasi lebih awal. ${ }^{7}$ Namun, intubasi dan penggunaan ventilator mekanik juga memiliki risiko (seperti ventilatorassociated pneumonia, trauma jalan napas, ventilator-associated lung injury, dan gangguan hemodinamik akibat ventilasi tekanan positif) yang menjadi pertimbangan apakah strategi ini lebih baik atau tidak untuk pasien. ${ }^{8}$ Beberapa penelitian mengenai waktu yang tepat untuk intubasi pada pasien COVID-19 telah dilakukan, namun hasil yang tersedia saat ini masih menjadi perdebatan.

Penelitian ini bertujuan untuk membandingkan kapan waktu yang paling tepat untuk dilakukannya intubasi pada pasien COVID-19 terinfeksi berat yang membutuhkan intensive care unit (ICU) dan tingkat mortalitas dari pasienpasien yang terintubasi tersebut.

\section{METODE PENELITIAN}

Penelitian tinjauan sistematis ini dilakukan berdasarkan panduan rekomendasi dari preferred reporting items for systematic reviews and meta-analysis protocols (PRISMA-P). ${ }^{9}$ Publikasi terkait diidentifikasi melalui mesin pencari Pubmed, Cochrane Library, dan ProQuest tanpa adanya pembatasan atau penyaringan pada waktu publikasi.

Kami memilih artikel penelitian yang memenuhi kriteria inklusi, di mana kriteria tersebut berupa randomized control trial (RCT) dan studi kohort yang meneliti waktu intubasi trakeal pada pasien COVID-19. Kami juga memasukkan artikel penelitian yang menunjukkan angka mortalitas

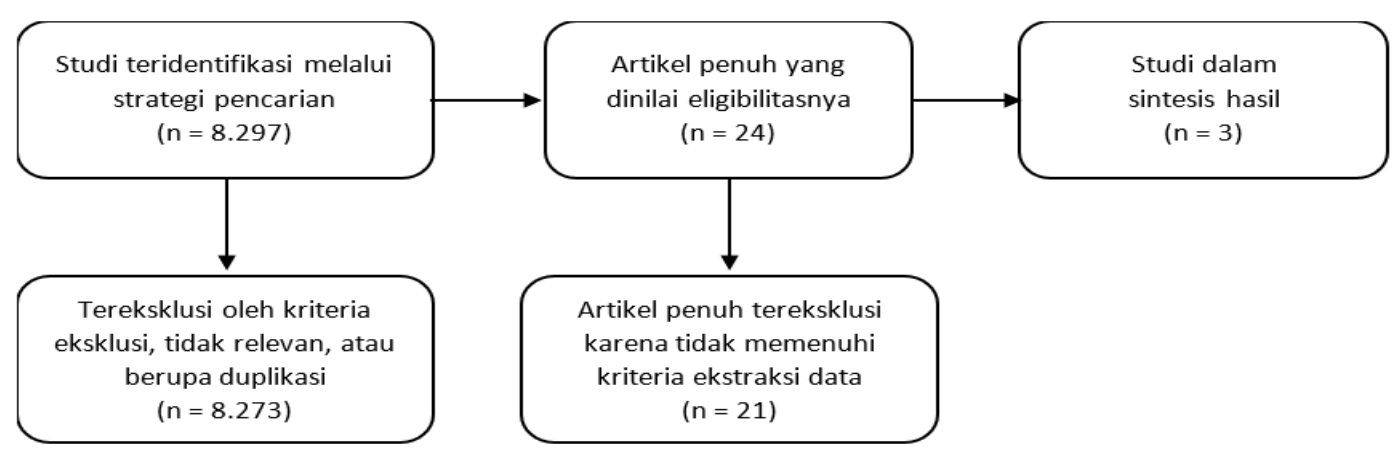

Gambar 1. Diagram Alur Proses Seleksi Artikel Studi 
pasien yang berhubungan dengan waktu dari intubasi trakeal. Kriteria ekslusi pada penelitian ini berupa artikel yang tidak terpublikasi secara penuh dan artikel yang tidak terpublikasi dalam bahasa Inggris.

Data yang didapatkan dari strategi pencarian sebanyak 8.297. Pencarian artikel terkait disaring berdasarkan judul, abstrak, kriteria inklusi, dan kriteria eksklusi. Sebanyak 24 artikel penuh tersisa dan kemudian kami menilai eligibilitasnya agar dapat dilakukan ekstraksi data. Tersisa 3 artikel yang dapat diikutsertakan ke dalam hasil penelitian.

\section{HASIL PENELITIAN}

Penelitian Hernandez-Romieu dkk. dilakukan pada 6 ICU COVID-19 di 4 rumah sakit Emory Healthcare yang berada di Atlanta dan Georgia. Terdapat 730 pasien yang terdiagnosis dengan COVID-19 dan 284 pasien di antaranya membutuhkan penanganan ICU. Secara keseluruhan, 175 pasien $(75,7 \%)$ menerima ventilasi mekanik pada beberapa poin selama masa perawatan ICU mereka. Median waktu dari saat pertama kali pasien berada di ICU sampai dilakukannya intubasi adalah 8,1 jam (interquartile range (IQR), 0,3-20,1 jam). Di antara 175 pasien tersebut, 76 pasien $(43,4 \%)$ diintubasi sebelum atau selama 8 jam perawatan ICU, 57 (32,6\%) diintubasi antara 8 sampai 24 jam, dan 42 pasien (24,0\%) diintubasi lebih dari atau pada 24 jam setelah perawatan ICU. Median waktu intubasi di antara pasien yang terintubasi lebih dari atau pada 24 jam setelah perawatan ICU adalah 2,3 hari (IQR, 1,2 - 3,1 hari) dengan rentang waktu $1,0-8,3$ hari. $^{10}$

Sebuah penelitian kohort observasional dilakukan oleh Siempos dkk. pada rumah sakit Evangelismos di Athena, Yunani. Penelitian dilakukan pada seluruh pasien dewasa $(>18$ tahun) dengan konfirmasi laboratorium terdeteksi COVID-19. Selama masa penelitian, 101 pasien memerlukan perawatan rumah sakit dan 42 pasien di antaranya membutuhkan perawatan ICU dikarenakan acute hypoxemic respiratory failure. Median waktu dari dirawat di rumah sakit sampai perawatan ICU adalah 0 hari (IQR, 0 - 3 hari), tetapi tidak ada data waktu saat pasien dirawat di ICU sampai

Tabel 1. Karakteristik Pasien

\begin{tabular}{|c|c|c|c|}
\hline Karakteristik Pasien & $\begin{array}{l}\text { Hernandez-Romieu }{ }^{10} \\
(n=175)\end{array}$ & $\begin{array}{l}\text { Siempos }^{11} \\
(n=42)\end{array}$ & $\begin{array}{l}\text { Lee }^{12} \\
\text { (n = 47) }\end{array}$ \\
\hline Usia & $66(56-75)$ & $65(58-71)$ & $70(63-77)$ \\
\hline Laki-laki & $97(55,4)$ & $34(81)$ & $28(59,6)$ \\
\hline Komorbiditas & $\mathrm{td}$ & $26(62)$ & $29(74)$ \\
\hline Diabetes & $100(57,1)$ & $7(17)$ & $17(44)$ \\
\hline Hipertensi & $77(44,0)$ & $\mathrm{td}$ & $18(46)$ \\
\hline Kardiovascular & $\mathrm{td}$ & $20(48)$ & $6(15)$ \\
\hline Gagal ginjal kronis & $50(28,6)$ & $\mathrm{td}$ & $3(7)$ \\
\hline ESRD / gagal ginjal & $22(12,6)$ & $1(2)$ & $\mathrm{td}$ \\
\hline Penyakit paru kronis & $33(18,9)$ & $4(10)$ & $4(10)$ \\
\hline Keganasan & $\mathrm{td}$ & $5(12)$ & $6(15)$ \\
\hline Demensia & $\mathrm{td}$ & $\mathrm{td}$ & $3(7)$ \\
\hline Penyakit serebrovaskular & $\mathrm{td}$ & $\mathrm{td}$ & $1(3)$ \\
\hline Penyakit hati kronis & $\mathrm{td}$ & $\mathrm{td}$ & $1(3)$ \\
\hline Skor SOFA & $9(7-12)$ & $4(4-6)$ & $3(2-7)$ \\
\hline Jumlah kelompok & 3 & 2 & $2 *$ \\
\hline
\end{tabular}


membutuhkan intubasi. Empat pasien tidak dapat dikategorikan dalam kelompok awal v.s terlambat atau tidak diintubasi dikarenakan sudah lebih awal terintubasi dari rumah sakit lain dan tidak tersedianya data yang berhubungan dengan kondisi pasien tersebut. Di antara 38 pasien, 14 pasien berada pada kelompok "intubasi awal" dan 24 pasien lainnya berada pada kelompok terlambat atau tidak diintubasi. Kelompok "terlambat atau tidak diintubasi" berisikan pasien yang menerima non-rebreather mask selama 24 jam atau lebih, atau yang menerima oksigen nasal kanul beraliran tinggi untuk beberapa periode waktu, atau menerima ventilasi mekanik non-invasif untuk beberapa periode waktu agar menghindari dilakukannya intubasi. ${ }^{11}$

Lee dkk. melakukan penelitian kohort retrospektif pada tiga rumah sakit rujukan tersier di Daegu, Korea. Data dikumpulkan dari pasien rawat inap dewasa ( $\geq 18$ tahun) dengan hasil konfirmasi laboratorium positif COVID-19. Pasien diklasifikasikan ke dalam dua kelompok berdasarkan pada penelitian sebelumnya yang dilakukan Kangelaris dkk.: (1) intubasi awal: intubasi/ventilasi mekanis dan memenuhi kriteria ARDS pada hari yang sama (dalam 24 jam), dan (2) awalnya tidak diintubasi: tidak dilakukan intubasi pada saat pertama kali dinilai dengan kriteria ARDS. Kelompok yang awalnya tidak diintubasi dibagi lagi menjadi dua sub-kelompok: (A) tidak pernah diintubasi: tidak membutuhkan intubasi sepanjang perawatan rumah sakit dan (B) terlambat diintubasi: tidak diintubasi pada hari didiagnosis menggunakan kriteria ARDS, tetapi diintubasi pada hari berikutnya pada saat penelitian. Terdapat 47 pasien yang diteliti, $23(48,9 \%)$ mendapatkan intubasi awal dan 24 $(51,1 \%)$ tidak langsung dilakukan intubasi. Di antara 24 pasien tersebut, 16 (34\%) di antaranya membutuhkan intubasi selama masa followup. Median interval waktu dari diagnosis ARDS sampai dilakukannya intubasi pada kelompok intubasi yang lebih lambat adalah 3 hari (IQR, 1 - 7 hari), tetapi tidak ada data yang ditampilkan untuk kelompok intubasi lebih awal. ${ }^{12}$

Ketiga penelitian tersebut memiliki karakteristik pasien yang hampir sama pada variabel usia dan komorbiditas, tetapi terdapat pula variasi yang luas pada proporsi jenis kelamin dan etnis terkait perbedaan lokasi penelitian. Terdapat pula variasi pada skor SOFA pasien pada tiap penelitian.

Di antara 175 pasien yang menerima ventilasi mekanik pada penelitian Hernandez-Romieu dkk., 63 pasien mengalami kematian $(36,0 \%)$. Median waktu dari intubasi sampai kematian adalah 10 hari (IQR, 4-16 hari). Pasien yang terintubasi kurang dari 8, 8-24 jam, dan lebih dari sama dengan 24 jam setelah membutuhkan ICU memiliki persentase mortalitas masingmasing 38,2\%, 31,6\%, dan 38,1\%. Tidak terdapat perbedaan yang signifikan pada tingkat mortalitas pasien di rumah sakit antara masing-

Tabel 2. Mortalitas rumah sakit antar kelompok dengan waktu intubasi yang berbeda.

\begin{tabular}{lll}
\hline Waktu Intubasi & Kematian & Nilai $\mathbf{p}$ \\
\hline Hernandez-Romieu ${ }^{10}$ & & \\
$<8$ jam $(\mathrm{n}=76)$ & $29(38,2)$ & 0,7 \\
$8-24$ jam $(\mathrm{n}=57)$ & $18(31,6)$ & \\
$>24$ jam $(\mathrm{n}=42)$ & $16(38,1)$ & \\
Siempos ${ }^{11}$ & & \\
Intubasi awal $(\mathrm{n}=14)$ & $3(21,4)$ & 0,48 \\
Ditunda/tidak diintubasi $(\mathrm{n}=24)$ & $8(33,3)$ & \\
Lee $^{12}$ & & \\
Intubasi awal $(\mathrm{n}=23)$ & $13(56,3)$ & 0,433 \\
Intubasi lama $(\mathrm{n}=16)$ & $7(43,8)$ & \\
Nilai dalam $\mathrm{n}(\%)$. &
\end{tabular}


masing kelompok $(p=0,7) \cdot{ }^{10}$

Pada penelitian Siempos dkk., 11 pasien meninggal (26\%) di antara 38 pasien yang membutuhkan ICU. Siempos dkk. menyimpulkan bahwa intubasi lebih awal v.s intubasi terlambat atau tidak diintubasi, tidak berhubungan dengan perburukan manifestasi klinis seperti mortalitas. Tidak ada perbedaan tingkat mortalitas yang signifikan antara kelompok $(p=0,48)$ di mana 3 pasien $(21 \%)$ meninggal pada kelompok intubasi lebih awal dan 8 pasien (33\%) meninggal pada kelompok intubasi terlambat atau tidak diintubasi. ${ }^{11}$

Data Lee dkk. menunjukkan persentase mortalitas yang tinggi antara 2 kelompok. Terdapat 13 pasien $(56,3 \%)$ mengalami kematian pada kelompok intubasi awal dan 7 pasien $(43,8 \%)$ pada kelompok intubasi yang terlambat. Tetapi tetap saja tidak ada perbedaan yang signifikan pada tingkat mortalitas dari masingmasing kelompok (dibandingkan hanya pada kelompok intubasi awal dan intubasi terlambat) $(p=0,433) \cdot{ }^{12}$

\section{PEMBAHASAN}

Hasil dari ketiga penelitian menilai hubungan antara waktu dilakukannya intubasi (awal v.s lama) dan laju mortalitas rumah sakit pada pasien dengan COVID-19. Didapatkan hasil dari keseluruhan dari penelitian tersebut bahwa intubasi yang dilakukan lebih awal maupun intubasi yang dilakukan lebih lama, tidak memiliki hubungan yang signifikan terkait kejadian mortalitas pasien dengan COVID-19 yang membutuhkan perawatan ICU. Hal ini berdasarkan masing-masing penelitian didapatkan hasil mortalitas yang tidak terlalu berbeda antara kedua kelompok dan didapatkan juga angka mortalitas yang lebih tinggi pada pasien yang terintubasi lebih awal, sesuai dengan data yang ditampilkan pada Tabel 3. ${ }^{10-12}$ Ketiga penelitian yang diikutsertakan dalam analisis hanya menyatakan bahwa keputusan intubasi (baik kriteria indikasi dan/atau waktu dilakukan intubasi) didasarkan pada keputusan dokter penanggung jawab tiap pasien dan tidak terdapat penjelasan lebih lanjut terkait hal ini. ${ }^{10-12} \mathrm{Hal}$ ini menyebabkan kami tidak dapat menganalisis lebih lanjut terkait perbedaan kriteria indikasi intubasi dari masing-masing penelitian dan kemungkinan terdapat pengaruh kondisi klinis tertentu yang mempengaruhi pertimbangan waktu intubasi dari pasien COVID-19 yang membutuhkan perawatan ICU. Berbeda dari penelitian yang dilakukan Zuccon dkk., 48 pasien terintubasi dengan parameter indikasi dilakukannya intubasi dengan melihat kadar SpO2 $\leq 92 \%$, laju pernapasan $\geq 28 x$ /menit, dan rasio $P / F \leq 300$, kemudian didapatkan bahwa intubasi lebih awal (<24 jam) pada 25 pasien (9 pasien mengalami kematian, 36\%) dan intubasi lebih lambat ( $>24$ jam) pada 23 pasien ( 12 pasien mengalami kematian, 52,2\%). ${ }^{13}$ Hal tersebut mendukung pernyataan bahwa intubasi lebih awal dapat mengurangi angka mortalitas.

Berdasarkan informasi klinis dan pendapat para ahli, intubasi awal direkomendasikan untuk menghindari dilakukannya prosedur intubasi pada keadaan hipoksemia berat yang dapat muncul pada fase terlambatnya penangganan penyakit, hal tersebut juga dapat menurunkan risiko mortalitas. ${ }^{14}$ Pertimbangan lainnya untuk dilakukan intubasi lebih awal berdasarkan rasionalitas pencegahan terjadinya self-inflicited lung injury (SILI) akibat usaha napas yang terlalu berat yang mengakibatkan peningkatan tekanan intrapleural pada pasien COVID-19 dengan gejala berat. ${ }^{15}$ Belum ada konsensus resmi yang merekomendasikan tentang waktu lebih awal untuk dilakukannya intubasi. Meskipun demikian, data pendukung lain menunjukkan bahwa evaluasi analisis gas darah selama 7 hari pada pasien non-survivors cenderung terjadi perburukan, baik sebelum dan sesudah dilakukannya intubasi. Hal tersebut dikatakan dapat menjadi pertimbangan lebih baik dilakukan intubasi lebih awal sebelum data analisis gas darah menjadi semakin memburuk. ${ }^{16}$ Namun tindakan intubasi lebih awal pada ketiga penelitian yang kami analisis menunjukkan tidak ada perbedaan yang signifikan terhadap angka mortalitas dibandingkan dengan waktu intubasi yang lebih lambat.

Data pada karakteristik pasien kami serupa dengan penelitian sebelumnya yang dilakukan Among dkk., yang menunjukkan bahwa usia tua dan faktor komorbiditas berhubungan dengan tingginya risiko dilakukannya intubasi dan peningkatan mortalitas. ${ }^{17}$ Penelitian pendukung 
lainnya menjelaskan secara lebih spesifik kesamaan pasien terkait peningkatan angka dilakukannya intubasi pada kelompok usia $>60$ tahun, berjenis kelamin laki-laki, dan memiliki komorbiditas diabetes dibandingkan pasien yang tidak memiliki faktor risiko tersebut. ${ }^{18}$ Patofisiologi yang mendasari usia tua lebih berisiko adalah akibat infeksi COVID-19 yang menginduksi penurunan level angiotensinconverting enzyme 2(ACE-2) yang berfungsi dalam regulasi sistem inflamasi, sedangkan level ACE-2 pada kelompok usia tua berada dalam kadar yang rendah. ${ }^{19} \mathrm{Hal}$ tersebut akan mengarahkan pada mudahnya terjadi mekanisme perburukan penyakit. Pada penelitian kami, diabetes menjadi komorbiditas utama yang ada pada ketiga artikel penelitian, dengan jumlah persentase yang cukup tinggi pada ketiganya, namun tidak dilakukan pembahasan secara pasti mana saja faktor komorbiditas yang dapat mempengaruhi kejadian mortalitas.

Perlu diperhatikan pula komplikasi yang paling sering dapat terjadi pada pasien COVID-19 yang terintubasi, di antaranya dapat berupa perburukan pernapasan, gagal ginjal, kegagalan fungsi hati, dan kemungkinannya terjadi lesi pada paru yang dipengaruhi oleh penggunaan ventilasi mekanik. ${ }^{13}$ Penggunaan ventilasi mekanik juga tidak akan memberikan dampak kesembuhan pada paru-paru. Hal tersebut hanya akan membuat pasien tetap hidup sampai mekanisme biologis pada tubuh mereka dapat melemahkan infeksi Coronavirus. ${ }^{20}$ Keterbatasan utama pada penelitian ini adalah definisi operasional yang berbeda pada tiga literatur mengenai waktu intubasi. Selain itu, kurangnya data terkait waktu spesifik kapan dapat dilakukannya intubasi dan kurangnya data mengenai pengaruh komorbiditas terhadap mortalitas. Terlebih lagi, terdapat pula beberapa kekurangan informasi terkait kriteria perawatan ICU dan faktor prediktif apa saja yang dapat mempengaruhi kebutuhan perawatan ICU.

\section{SIMPULAN}

Penelitian ini mengidentifikasi hubungan antara waktu intubasi yang tepat dan tingkat mortalitas dari pasien COVID-19 dengan perawatan ICU. Berdasarkan data penemuan di atas, kami menyimpulkan bahwa intubasi lebih awal tidak memiliki nilai yang signifikan untuk menurunkan angka mortalitas pada pasien dengan COVID-19, namun masih diperlukan penelitian lebih lanjut terkait faktor prediktif lainnya serta mengenai intubasi awal pada pasien COVID-19 agar dapat dilakukan metaanalisis.

\section{DAFTAR PUSTAKA}

1. Pourbagheri-sigaroodi $A$, Bashash $D$, Fateh $\mathrm{F}$, Abolghasemi $\mathrm{H}$. Laboratory findings in COVID-19 diagnosis and prognosis. 2020;1:475-82.

2. Benvenuto D, Giovanetti M, Ciccozzi A, Spoto S, Angeletti S, Ciccozzi M. The 2019-new coronavirus epidemic: evidence for virus evolution. J Med Virol. 2020;92(4):455-9.

3. Perlman S. Another decade, another coronavirus. N Engl J Med. 2020;382(8):7602.

4. World Health Organization. WHO coronavirus (COVID-19) dashboard [Internet]. 2021. p. 1. Available from: https://covid19.who.int/

5. Wu YC, Chen CS, Chan YJ. The outbreak of COVID-19: an overview. J Chinese Med Assoc. 2020;83(3):217-20.

6. Yang $X, Y u Y, X u J$, Shu $H, X i a ~ J, ~ L i u ~ H$, et al. Clinical course and outcomes of critically ill patients with SARS-CoV-2 pneumonia in Wuhan, China: a single-centered, retrospective, observational study. Lancet Respir Med. 2020;8(5):475-81.

7. Zuo M, Huang Y, Ma W, Xue Z, Zhang J, Gong $Y$, et al. Expert recommendations for tracheal intubation in critically ill patients with Noval Coronavirus Disease 2019. Chinese Med Sci J. 2020;35(2):105-9.

8. Ziehr DR, Alladina J, Petri CR, Maley JH, Moskowitz A, Medoff BD, et al. Respiratory pathophysiology of mechanically ventilated patients with COVID-19: a cohort study. Am J Respir Crit Care Med. 2020;201(12):1560-4.

9. Moher D, Shamseer L, Clarke $M$, Ghersi $D$, Liberati A, Petticrew $M$, et al. Preferred reporting items for systematic review and meta-analysis protocols (PRISMA-P) 2015 statement. Syst Rev. 2015;4(1):1.

10. Hernandez-romieu AC, Adelman MW, Hockstein MA, Robichaux CJ, Edwards JA, 
Fazio JC, et al. Timing of intubation and mortality among critically ill Coronavirus Disease 2019 patients: a single-center cohort study. Crit Care Med. 2020;1-9.

11. Siempos II, Xourgia E, Ntaidou TK, Zervakis D. Effect of early vs. delayed or no intubation on clinical outcomes of patients with COVID-19: an observational study. Front Med. 2020;7:1-6.

12. Lee YH, Choi K-J, Choi SH, Lee SY, Kim KC, Kim EJ, et al. Clinical significance of timing of intubation in critically ill patients with COVID-19: a multi-center retrospective study. J Clin Med. 2020;9(9):2847.

13. Zuccon W, Comassi P, Adriani L, Bergamaschini $G$, Benelli G, Buscarini $E$, et al. Intensive care for seriously ill patients affected by novel coronavirus SARS-CoV-2: experience of the Crema hospital, Italy. Am J Emerg Med. 2020.

14. Yao W, Wang T, Jiang B, Gao F, Wang L, Zheng $\mathrm{H}$, dkk. Emergency tracheal intubation in 202 patients with COVID-19 in Wuhan, China: lessons learnt and international expert recommendations. 2020;125(1):28-37.

15. Rola P, Farkas J, Spiegel R, Kyle-Sidell C, Weingart $S$, Duggan $L$, et al. Rethinking the early intubation paradigm of COVID-19: time to change gears? Clin Exp Emerg Med. 2020;7(2):78-80.

16. Zhang L, Li J, Zhou M, Chen Z. Summary of 20 tracheal intubation by anesthesiologists for patients with severe COVID-19 pneumonia: retrospective case series. J Anesth. 2020;34(4):599-606.

17. Among $M$, Magleby $R$, Westblade $L F$, Trzebucki A, Simon MS, Rajan M, dkk. Impact of SARS-CoV-2 viral load on risk of intubation and mortality among hospitalized patients with coronavirus disease 2019. 2020;1-33.

18. Hur K, Price CPE, Gray EL, Gulati RK, Maksimoski $M$, Racette SD, dkk. Factors associated with intubation and prolonged intubation in hospitalized patients with COVID-19. Otolaryngol - Head Neck Surg (United States). 2020;163(1):170-8.

19. AlGhatrif M, Cingolani O, Lakatta EG. The dilemma of Coronavirus Disease 2019, aging, and cardiovascular disease. Nat Med. 2020;11(8):875-9.

20. Tobin MJ. Basing respiratory management of COVID-19 on physiological principles. Am J Respir Crit Care Med. 2020;201(11):131920. 